\title{
PERLINDUNGAN HUKUM PROFESI GURU DALAM PERSPEKTIF HUKUM POSITIF
}

\author{
Prof. Dr. Harun \\ harun1@ums.ac.id
}

\section{PENDAHULUAN}

Guru adalah profesi tua bahkan profesi yang sangat mulia dan terhormat. Profesi ini apabila dilihat dari peran dan fungsinya adalah profesi "kenabian", mengingat bahwa misi besar semua utusan Allah adalah mengajar manusia untuk U'budullah Walatusriku bihi syai a (menyembah Allah dan tidak mensyarikatkan Allah). Guru di Indonesia dalam mengabdikan diri untuk kehidupan bangsa ini adalah melakukan upaya mencerdaskan dan meningkatkan kualitas manusia Indonesia menjadi manusia beriman, bertakwa, dan berakhlak mulia serta menguasai ilmu pengetahuan, teknologi, dan seni dalam mewujudkan masyarakat yang berkemajuan, adil, makmur, dan beradab.

Keinginan besar para pejuang kemerdekaan negara ini, terabadikan pada alinea ke IV Pembukaan Undang-Undang Dasar Negara Republik Indonesia Tahun 1945, yakni "melindungi segenap bangsa dan seluruh tumpah darah Indonesia dan untuk memajukan kesejahteraan umum, mencerdaskan kehidupan bangsa, dan ikut melaksanakan ketertiban dunia berdasarkan kemerdekaan, perdamaian abadi, dan keadilan sosial". Mewujudkan tujuan tersebut lewat dunia pendidikan adalah merupakan pilihan yang dianggap paling strategis dan cerdas untuk pencapaian tujuan yang lainnya.

Berbagai harapan digantungkan pada aktifitas pendidikan yakni kehidupan bangsa cerdas, berkualitas beriman, bertakwa, dan berakhlak mulia serta menguasai ilmu pengetahuan, teknologi, dan seni dalam mewujudkan masyarakat yang maju, adil, makmur, dan beradab berdasarkan Pancasila dan Undang-Undang Dasar Negara Republik Indonesia Tahun 1945. Diujung dari semua harapan tersebut adalah guru sebagai pengemban cita-cita besar tersebut, karena coretan pena serang guru adalah bangunan karakter bangsa ini kedepan.

Guru, dari fungsi, peran, dan kedudukannya dalam posisi strategis dalam pembangunan nasional di bidang pendidikan, sehingga selayaknnya dikembangkan sebagai profesi yang bermartabat, profesional dalam tugas utama mendidik, mengajar, membimbing, mengarahkan, melatih, menilai, dan mengevaluasi peserta didik.

Keberadaan organisasi profesi keguruan, adalah merupakan suatu keharusan profesional yang sangat diperlukan. Peran melindungi dan mengayomi bahkan ketika guru dianggap tidak profesional dalam melaksanakan profesinya, organisasi profesilah harus tampil lebih di awal untuk melakukan evaluasi dan verifikasi. Karena organisasi profesilah yang lebih berkompeten melakukan evaluasi dan verifikasi. Uji profesional guru dan profesi yang lain hanya mungkin dilakukan oleh fihak yang memahami dan mendalami profesi tersebut. Organisasi profesilah yang seharusnya membina dan melindungi dengan memakai pendekatan kode etik profesi keguruan. Yang didalamnya terdapat perangkat profesional dan mandiri yang menjalankan peran tersebut, yakni Dewan Kehormatan Guru Indonesia (DKGI)

Dewan Kehormatan Guru Indonesia (DKGI) adalah perangkat kelengkapan organisasi PGRI yang dibentuk untuk menjalankan tugas dalam memberikan saran, pendapat, pertimbangan, penilaian, penegakan, dan pelanggaran disiplin organisasi dan etika profesi guru.Peraturan tentang Dewan Kehormatan Guru Indonesia adalah pedoman pokok dalam mengelola Dewan Kehormatan Guru Indonesia, dalam hal penyelenggaraan tugas dan wewenang bimbingan, pengawasan, dan penilaian Kode Etik Guru Indonesia.

Guru sebagai pendidik profesional dalam melaksanakan tugasnya akan bersinggungan dengan subyek yang bernama peserta didik, orang tua peserta didik, masyarakat pemerhati. 
Subyek tersebut pada saat guru melaksanakan tugas profesi dimungkinkan akan terjadi beda tafsir antara guru profesional dengan fihak lain,organisasi profesi secepat mungkin berperan secara profesional, karena tidak jarang guru profesional harus bertanggungjawab diluar apa yang menjadi tanggungjawabnya secara profesional.

Kemungkinan anggapan terjadinya pelanggaran yang dilakukan seorang guru dalam melakukan profesinya, ada kemungkinan termasuk pelanggaran dalam melakukan profesi dan masukKode Etik Guru Indonesia serta di luar kode etik profesi.Untuk itu harus dibedakan pelanggaran hukum administrasi atau pelanggaran hukum di ranah pidana attau ranah hukum yyang lain.

Guru secara normatif, memang telah mendapatkan perlindungan, sebagaimana ketentuan pasal 39 Undang-Undang Nomor 14 Tahun 2005 (1) "Pemerintah, pemerintah daerah, masyarakat, organisasi profesi, dan/atau satuan pendidikan wajib memberikan perlindungan terhadap guru dalam pelaksanaan tugas". Rumusan undang-undang tersebut telah memberikan dan mewajibkan adanya perlindungan kepada guru dalam tugasnya. Juga pada ayat (2)nya menjelaskan ruang lingkup perlindunginya yang meliputi "Perlindungan sebagaimana dimaksud pada ayat (1) meliputi hukum, perlindungan profesi, serta perlindungan keselamatan dan kesehatan kerja"Ketentuan ini membedakan secara tegas tentang perbedaan antara perlindungan hukum, perlindungan profesi, perlindungan keselamatan kerja dan perlindungan kesehatan kerja.

Apakah hal ini telah terlaksana sebagaimana yang seharusnya? Untuk itulah masalah tersebut perlu dilakukan pembahasan dan analisis secara lebih mendalam. Mengingat saat ini terdapat berbagai kasus yang mengusik peran profesionalisasi guru dan kriminalisasi profesi.

\section{MIMPI LAHIR BANGSA YANG CERDAS}

Keberadaan sumber daya manusia yang cerdas telah dirasakan sebagai sesuatu yang sangat diperlukan dalam menjalankan kehidupannya bersama, baik sebagai individu dan bangsa dalam melakukan hubungan internal ataupun dengan bangsa lain di dunia. Keadaan terjajah oleh bangsa lain,demi membuahkan kesadaran akan pentingnya hidup merdeka.Serta akibat dari kondisi ketertinggalan dalam dunia pendidikan, sehingga bangsa lain dengan seenaknya memperlakukan kita sebagai bangsa terjajah.

Kesadaran nilai pentingnya kemerdekaan dan untuk apa merdeka merupakan kesadaran akan pentingnya sumberdaya manusia cerdas dan merupakan potensi dasar untuk meraih tujuan yang lain.Sebagaimana tujuan melindungi segenap bangsa dan seluruh tumpah darah indonesia dan untuk memajukan kesejahteraan umum, dan ikut melaksanakan ketertiban dunia berdasarkan kemerdekaan, perdamaian abadi, dan keadilan sosial.

Dengan demikian tampak jelas bahwa kehidupan berbangsa yang dicitakan tidak hanya untuk kepentingan diri sendiri sebagai bangsa, tetapi juga bagaimana mampu menolong bangsa lain untuk melaksanakn kehidupan yang lebih baik dan bermartabat.

Hal ini ditindak lanjuti dengan pasal 31 batang tubuh UUDNKRI 1945 (1), (2), dan (3) yang berbunyi:

Pasal 31 ayat (1) “Setiap warga Negara berhak mendapat pendidikan”. Ayat (2) "Setiap warga Negara wajib mengikuti pendidikan dasar dan pemerintah wajib membiayainya”. Ayat (3) "Pemerintah mengusahakan dan menyelenggarakan satu sistem pendidikan nasional, yang meningkatkan keimanan dan ketakwaan serta akhlak mulia dalam rangka mencerdaskan kehidupan bangsa, yang diatur dengan undangundang".

Dengan rumusan dalam pasal UUD lebih menjabarkan dan memantapkan komitmen dasar bangsa ini dalam mewujudkan upaya mencerdaskan kehidupan bangsanya. Tujuan yang ada pada pasal 31 UUD NKRI 1945 tersebut ditindak lanjuti dengan kehadiran Undang-undang nomor 20 tahun 2003 tentang sistem pendidikan nasional. Tujuan besar tersebut tergambar sebagaimana 
visipada Undang-undang tersebut, yang menegaskan bahwa tujuan pendidikan bangsa secara nasional adalah "terwujudnya sistem pendidikan sebagai pranata sosial yang kuat dan berwibawa untuk memberdayakan semua warga negara Indonesia berkembang menjadi manusia yang berkualitas sehingga mampu dan proaktif menjawab tantangan zaman yang selalu berubah.

Mimpi sistem pendidikan di Indonesia merupakan dari pranata sosial adalah sistem pendidikan yang dibangun adalah merupakan salah satu jalinan sub-sub sistem dalam masyarakat Indonesia yang tidak terpisahkan dari keberadaan masyarakat secara keseluruhan. Sehingga keberadaan pendidikan nasional adalah merupakan jalinan infra struktur dari kehidupan masyarakat Indonesia secara kuat,berwibawa serta bermartabat.

Mimpi itu juga menggambarkan begitu besarnya keinginan dan cita-cita bangsa ini terhadap keberadaan sistem pendidikan adalah bagian dari kehidupan masyakatnya secara me lembaga. Lembaga itulah diharapkan mampu melakukan aktifittasnya "memberdayakan semua warga negara Indonesia yang berkembang menjadi manusia yang berkualitas sehingga mampu dan proaktif menjawab tantangan zaman yang selalu berubah". Kuatnya komitmen tersebut, pada saat terjadi perubahan UUD 1945 dituangkan dalam pasal 31(4) sehingga pada masa terjadi perubahan lahirlah pasal yang mengatakan bahwa: "Negara memprioritaskan anggaran pendidikan sekurangkurangnya dua puluh persen dari anggaran pendapatan dan belanja negara serta dari aggaran pendapatan dan belanja daerah untuk memenuhi kebutuhan penyelenggaraan pendidikan nasional"

Sehingga apabila dilihat dari norma yang mengaturnya maka begitu mapan dengan besaran anggaran pendidikan yang ditetapkan, dapat dimaknai juga bahwa besarnya komitmen bangsa ini terhadap upaya mencerdaskan kehidupan bangsa dan disisi yang lain berarti betapa berat peran guru dalam pengemban tugas ini dan mencapai tujuan pendidikan nasional.

\section{Guru Profesional}

Tanggungjawab mewujudkan visi besar pendidikan nasional untuk "memberdayakan semua warga negara Indonesia berkembang menjadi manusia yang berkualitas sehingga mampu dan proaktif menjawab tantangan zaman yang selalu berubah" hal initertumpu pada guru profesional sebagai ujung tombak terwujudnya tujuan tersebut.

Didahului dengan kelahiran Undang-Undang Nomor 30 tahun 2003 tenttang Pendidikan Nasional dan diikuti dengan Undang-undang Republik Indonesia nomor 14 tahun 2005 tentang guru dan dosen, menjelaskan bahwa guru adalah "pendidik profesional dengan tugas utama mendidik, mengajar, membimbing, mengarahkan, melatih, menilai, dan mengevaluasi peserta didik pada pendidikan anak usia dini jalur pendidikan formal, pendidikan dasar, dan pendidikan menengah"

Pengertian profesional dalam undang-undang tersebut dimaknai sebagai "pekerjaan atau kegiatan yang dilakukan oleh seseorang dan menjadi sumber penghasilan kehidupan yang memerlukan keahlian, kemahiran, atau kecakapan yang memenuhi standar mutu atau norma tertentu serta memerlukan pendidikan profesi'.

Untuk memaknai secara lebih dalam bahasan ini perlu diurai secara terinci dari pengertian profesional dan yang paling awal adalah pengertian rumusan "pekerjaan atau kegiatan yang dilakukan oleh seseorang dan menjadi sumber penghasilan kehidupan", yang pada pengertian secara umum, biasa pengertian profesional dilawankan dengan "amatiran" yang berarti secara "sambilan" dilakukan dengan "paruh waktu", yang dilakukan "bukan sesuatu yang sesungguhnya". Sedangkan guru berdasar undang-undang ini adalah aktifitas yang dilakukan disertai dedikasi yang tinggi, atau sepenuh hati, yang "melibatkan potensi lahir dan batin dalam melaksanakannya dan untukmencapai tujuannya, tanpa terpancang pada waktu dan kesempatan. Sebagaimana falsafah "di gugu lan di tiru" dan "guru kencing berdiri murid kencing berlari' 'Untuk itu selayaknya dalam pemberian penghargaan profesi guru, undangundang memberi amanah yang layak sebagai sumber penghasilan kehidupan. 
Lebih lagi kalau mempertimbangkan bahwa guru dalam melakukan kegiatannya tidak hanya berdedikasi saja, tetapi juga harus didasarkan pada "memerlukan keahlian, kemahiran, atau kecakapan yang memenuhi standar mutu atau norma tertentu".

Prasyarat keahlian, kemahiran, atau kecakapan adalah merupakan prasyarat khusus yang hanya dimiliki subyek tetentu, dan untuk memilikinya diperlukan pendidikkan dan latihan, serta proses yang cukup melelahkan dan dalam waktu yang panjang. Belum lagi prasyarat "memenuhi standar mutu atau norma tertentu" yang berarti seluruh tindakannya dalam menggunakan kemampuannya terukur secara keilmuan dan akurasi secara sosial.

Dengan pengertian lain pengetahuan dan hal-hal yang menyertainya adalah prasyarat yang bersifat khusus dan tidak dimiliki dan dimengerti oleh setiap orang. Dengan konsekwensi untuk memahami apakah profesionalisme telah dilakukan ataupun belum atau tepat atau tidaknya hanya dapat diukur oleh fihak yang profesonal dalam bidangnya dan yang telah teruji acurasinya.

Pasal 8 Undang-Undang Nomor 14 Tahun 2005 menjelaskan bagaimana kemammpuan profesional guru di ukur dengan dan kewajiban yang meliputi memiliki kualifikasi akademik, kompetensi, sertifikat pendidik, sehat jasmani dan rohani, serta memiliki kemampuan untuk mewujudkan tujuan pendidikan nasional. Dengan tolok ukur tersebutseseorang guru dianggap profesional dan dianggap berkompetensi melaksanakan tugasnya. Kompetensi diukur dengan ukuran yang meliputi, sebagaimana pasal 10 Undang-Undang Nomor 14 Tahun 2005, adalah meliputi kompetensi pedagogik, kompetensi kepribadian, kompetensi sosial, dan kompetensi profesional yang diperoleh melalui pendidikan profesi.

Pengakuan kedudukan guru sebagai tenaga profesional dibuktikan dengan sertifikat pendidik dan hanya guru yang memenuhi syarat yang memiliki sertifikat pendidik. Adapun sertifikat pendidik hanya dapat di keluarkan, berdasar pasal 11 Undang-Undang Nomor 14 tahun 2005, yakni: (1) diselenggarakan oleh perguruan tinggi yang memiliki program pengadaan tenaga kependidikan yang terakreditasi dan ditetapkan oleh pemerintah; (2) sertifikasi pendidik dilaksanakan secara objektif, transparan, dan akuntabel.

Pasal 7 Undang-Undang Nomor 14 tahun 2005

a. Profesi guru dan profesi dosen merupakan bidang pekerjaan khusus yang dilaksanakan berdasarkan prinsip sebagai berikut:

1) memiliki bakat, minat, panggilan jiwa, dan idealisme;

2) memiliki komitmen untuk meningkatkan mutu pendidikan, keimanan, ketakwaan, dan akhlak mulia;

3) memiliki kualifikasi akademik dan latar belakang pendidikan sesuai dengan bidang tugas;

4) memiliki kompetensi yang diperlukan sesuai dengan bidang tugas;

5) memiliki tanggung jawab atas pelaksanaan tugas keprofesionalan;

6) memperoleh penghasilan yang ditentukan sesuai dengan prestasi kerja;

7) memiliki kesempatan untuk mengembangkan keprofesionalan secara berkelanjutan dengan belajar sepanjang hayat;

8) memiliki jaminan perlindungan hukum dalam melaksanakan tugas keprofesionalan; dan

9) memiliki organisasi profesi yang mempunyai kewenangan mengatur hal-hal yang berkaitan dengan tugas keprofesionalan guru.

Dengan demikian secara normatif bagaimana membangun guru profesional telah diatur dan proses serta lembaga yang kompetenpun telah ditentukan disertai indikatornya. Namun pada kenyataannya diperlukan kerja keras dan besar dari semua komponen praktisi dan akademisi untuk mewujudkannya,bahkan diperlukan partisipasi fihak ke tiga dalam mewujudkannya dan mengawal selama perjalanannya. 
Tindakan guru dalam melakukan profesinya dapat dilakukan penilaian ketepatan menjalankan profesi oleh fihak yang memahami profesi secara profesional, disinilah diperlukan organisasi profesi, yang didalamnya terdapat funsional Dewan Kehormatan Guru. Sehingga apabila terdapat perbedaan penafsiran atas perbuatan yang dilakukan atau bahkan pelanggaran yang dilakukan oleh guru profesional, hanya dapat dilakukan penilaian oleh fihak yang memahami profesi yakni Dewan Kehormatan Guru.

\section{ORGANISASI PROFESI, KODE ETIK GURU DAN DEWAN KEHORMATAN GURU}

Pada bagian awal Keputusan Konggres PGRI ke XXI/ PGRI/ 2013 No. VI/Konggres/XXI/ PGRI/ 2013 tentang Kode Etik Guru Indonesia, mengajak pada semua fihak bahwa pendidikan adalah infra struktur masyarakat Indonesia. Dan profesi Guru adalah sebagai pendidik profesonal dan sangat dihormati dan di mulyakan dalam struktur masyarakat Indonesia. Oleh karena itu moralitas guru harus senantiasa terjaga mengingat bahwa martabat dan kemulyaannya adalahmerupakan unsur dasar dan keunggulannya terletak pada perilaku, akal budi, dan pengabdiannya.

Guru merupakan pengemban tugas kemanusiaan dengan mengutamakan kebajikan dan mencegahdari kehinaan serta kemunkaran. Dalam mencerdaskan kehidupan bangsa dan membangun watak, budaya dan mengantarkan bangsa Indonesia pada kehidupan masyarakat yang maju adil dan makmur serta beradab berdasarkan pancasila dan UUD 1945.

Guru dituntut untuk menjalankan profesinya dengan ketulusan hati dan menggunakan keandalan kompetensi sumber daya dalam mewujudkan tujuan pendidikan nasional yaitu berkembangnya potensi peserta didik menjadi manusia utuk yang beriman dan bertaqwa serta menjadi warga negara yang baik, demokratis dan bertanggungjawab.

Pelaksanaan tugas guru Indonesia terwujud dan menyatu dalam prinsip ing ngarso sun tulodo ing madya mangun karso tut wuri handayani

\section{Organisasi Profesi Guru Dan Kode EtikGuru}

Untuk menggambarkan hubungan antara guru dengan organissasi profesi, maka dapat dilihat pada pasal 41 (1) Undang-Undang Nomor14 tahun 2005 yang menyatakan bahwa "Guru membentuk organisasi profesi yang bersifat independen" Dengan demikian undangundang telah mengamanatkan pada guru untuk membentuk organisasi profesi yang bersifat independen. Sehingga keberadaan organisasi profesi tersebut secara normatif dianggap keberdaannya atas amanah undang-undang dan mengikat pada anggotanya

Lebih lagi berdasar ayat (2) Undang-Undang Nomor14 tahun 2005 menjelaskan tenttang fungsi nya sebagaimana "Organisasi profesi sebagaimana dimaksud pada ayat (1) berfungsi untuk memajukan profesi, meningkatkan kompetensi, karier, wawasan kependidikan, perlindungan profesi, kesejahteraan, dan pengabdian kepada masyarakat". Ayat (3) "Guru wajib menjadi anggota organisasi profesi”. (4) Pembentukan organisasi profesi sebagaimana dimaksud pada ayat (1) dilakukan sesuai dengan peraturan perundang-undangan. (5) Pemerintah dan/atau pemerintah daerah dapat memfasilitasi organisasi profesi guru dalam pelaksanaan pembinaan dan pengembangan profesi guru.

Dari pasal 41 tersebut cukup dapat menjadi dasar yang menjelaskan hubungan antara guru sebagai profesi dengan organisasi profesi dan fungsi perlindungan profesi yang wajib dilakukan oleh organisasi rofesi dan PGRI adalah sebagai organisasi profesi guru.

Sedang pada pasal 42 Undang-Undang Nomor14 tahun 2005 memberikan apa yang menjadi kewenangan Organisasi profesi guru, yakni:

a. menetapkan dan menegakkan kode etik guru;

b. memberikan bantuan hukum kepada guru;

c. memberikan perlindungan profesi guru;

d. melakukan pembinaan dan pengembangan profesi guru; dan

e. memajukan pendidikan nasional. 
Dengan pasal 42 jelas wewenang yang dapat dilakukan oleh organisasi profesi yang meliputi: menetapkan kode etik beserta penegakkannya, memberi bantuan hukum, perlindungan profesi, pengembangan profesi dan memajukan pendidikan nasional.

Adapun isi kode etik, sebagaimana pasal 43 (1) Undang-Undang Nomor 14 tahun 2005 sebagai berikut"Untuk menjaga dan meningkatkan kehormatan dan martabat guru dalam pelaksanaan tugas keprofesionalan, organisasi profesi guru membentuk kode etik" dan pada ayat (2) "Kode etik sebagaimana dimaksud pada ayat (1) berisi norma dan etika yang mengikat perilaku guru dalam pelaksanaan tugas keprofesionalan".

\section{Dewan Kehormatan Guru}

Keberadaan Dewan Kehormatan Guru sebagaimana pasal 44 (1) Undang-Undang Nomor 14 tahun 2005 dibentuk oleh organisasi profesi guru, dengan tugas utama mengawasi dan menegakkan kode etik guru dalam rangka mewujudkan guru profesional, bermartabat, yang mampu melahirkan generasi baru yang cerdas, bermoral, beriman dan bertaqwa serta menjadi warga negara yang baik, demokratis dan bertanggungjawab.

DKGI adalah perangkat kelengkapan organisasi PGRI yang dibentuk untuk menjalankan tugas dan memberikan saran, pendapat dan pertimbangan, penilaian, penegakkan, dan pelanggaran disiplin ornanisasi dan etika profesi guru. Sedang Peraturan tentang DKGI adalah pedoman pokok dalam mengelola DKGI, dalam menyelenggarakan dan wewenang bimbingan, pengawasan, dan penilaian Kode Etik Guru Indonesia.

Adapun mekanisme pembentukan dewan kehormatan, tugas pokok dan wewenangnya termmuat pada ayat (2) yakni“Keanggotaan serta mekanisme kerja dewan kehormatan guru sebagaimana dimaksud pada ayat (1) diatur dalam anggaran dasar organisasi profesi guru". Ayat (3) yakni“"Dewan kehormatan guru sebagaimana dimaksud pada ayat (1) dibentuk untuk mengawasi pelaksanaan kode etik guru dan memberikan rekomendasi pemberian sanksi atas pelanggaran kode etik oleh guru". Ayat (4) yakni "Rekomendasi dewan kehormatan profesi guru sebagaimana dimaksud pada ayat (3) harus objektif, tidak diskriminatif, dan tidak bertentangan dengan anggaran dasar organisasi profesi serta peraturan perundang-undangan”. Dan ayat (5) berisi tentang" Organisasi profesi guru wajib melaksanakan rekomendasi dewan kehormatan guru sebagaimana dimaksud pada ayat (3)".

\section{Kode Etik Guru}

Adapun pengertiannya adalah:

\begin{tabular}{|c|c|}
\hline No & Pengertian \\
\hline 1 & $\begin{array}{l}\text { Kode Etik Guru Indonesia adalah norma dan asas yang disepakati dan diterima oleh guru-guru Indonesia } \\
\text { sebagai pedoman sikap dan perilaku dalam melaksanakan tugas profesi sebagai pendidik, anggota } \\
\text { masyarakat, dan warga negara. }\end{array}$ \\
\hline 2 & $\begin{array}{l}\text { Pedoman sikap dan perilaku sebagaimana yang dimaksud pasa ayat (1) pasal ini adalah nilai-nilai moral } \\
\text { yang membedakan perilaku guru yang baik dan buruk, yang boleh dan tidak boleh dilaksanakan selama } \\
\text { menunaikan tugas-tugas profesionalnya untuk mendidik, mengajar, membimbing, mengarahkan, melatih, } \\
\text { menilai, dan mengevaluasi peserta didik, serta pergaulan sehari-hari di dalam dan di luar sekolah. }\end{array}$ \\
\hline
\end{tabular}

Sebagaimana telah di amanatkan oleh Keputusan Konggres ke XXI/ PGRI/ 2013 No.VI/ Konggres/XXI/PGRI/ 2013 tentang Kode Etik Guru Indonesia

\section{a. Pasal 1 Kewajiban Umum}

1) Menjunjung tinggi, menghayati, dan mengamalkan sumpah/ janji guru

2) Mela ksanakan tugas utama mendidik, mengajar, membimbing, mengarahkan, 
melatih, menilai dan mengevaluasi peserta didik untuk mewujudkan tujuan pendidikan nasioanl

\section{b. Pasal 2 Kewajiban Guru Terhadap Peserta Didik}

1) Bertindak profesional dalam melaksanakan tugas mendidik, mengajar, membimbing, mengarahkan, melatih, menilai, dan mengevaluasi proses dan hasil belajar peserta didik

2) Membrikan layanan pembelajaran berdasarkan karakteristik individual serta tahapan tumbuh kembang kejiwaan peserta didik

3) Mengembangkan suasana pembelajaran yyang aktif, kreatif, efektif dan menyenangkan

4) Menghormati martabat dan hak hak sertamemperlakukan peserta didik secara adil dan obyektif

5) Melindungi peserta didik dari segala tindkan dan dapat mengganggu perkembangan, proses belajar, kesehhatan dan keamanan bagi peserta didik

6) Menjaga kerahasiaan pribadi peserta didik, kecuali dengan alasan yang dibenarkan berdasarkan hukum, kepentingan pendidikan, kesehatan. Dan kemanusiaan.

7) Menjaga hubungan profesional dengan peserta didik dan tidak memanfaatkan untuk keuntungan pribadi dan / atau kelompok dan tidak melanggar norma yang berlaku.

\section{c. Pasal 3 Kewajiban Guru Terhadap Orang Tua / Wali Peserta Didik}

1) Menghormati hak orang tua/ wali peserta didik untuk berkonsultasi dan memberikan informasi secara jujur dan obyektif mengenai kondisi dan perkembangan belajar peserta didik

2) Membina hubungan kerja sama dengan ortu/wali peserta didik dalam melaksanakan proses pendidikan untuk peningkatan mutu pendidikan

3) Menjaga hubungan professional dengan ortu/wali peserta didik dan tidak memanfaatkan untuk memperoleh keuntungan pribadi.

\section{d. Pasal 4 Kewajiban Guru Terhadap Masyarakat}

1) Menjalin komunikasi yang efektif dan kerjasama yang hharmonis dengan masyarakkaat untuk memmajukan dan mengembangkan pendidikan

2) Mengakomodasi aspirasi dan keinginan masyarakat dalam pengembnagan dan peningkatan kualitas pendidikan .

3) Bersikap responsif terhadap perubahan yang terjadi dalam masyarakat dengan mengindahkan norma dan sistem nilai yang berlaku.

4) Bersama-sama dengan masyarakat berperan aktif untuk menciptakan lingkungan sekolah hyang kondusif

5) Menjunjung tinggi kehormatan dan martabat serta menjadi panutan bagi masyarakat.

\section{e. Pasal 5 Kewajiban Guru Terhadap Teman Sejawat}

1) Membangun suasana kekeluargaan, solidaritas, dan saling menghormasi antar teman sejawat di dalam maupun diluar satuan pendidikan

2) Saling berbagi ilmu pengetahuan, tehnologi, seni, ketrampilan, dan pengalaman serta saling memotivasi untuk meningkatkan profesionalitas dan martabat guru

3) Menjaga kehormatan dan rahasia pribadi teman sejawat

4) Menghindari tindakan yang berpotnsi menciptakan komplik antar teman sejjawat 


\section{f. Pasal 6 Kewajiban Guru Terhadap Profesi}

1) Menjujung tinggi jabbatan guru sebagai profesi

2) Mengembangkan profeionalisme secara berkelanjutan, sesuai kemmajuan ilmu pengetahuan dan tehnologi untuk meningkatkan mutu pendidikan

3) Melakukan tindakan dan / atau mengeluarkan pendapat yang tidak merendahkan martabbat profesi.

Dengan kode etik tersebut diharapkan Guru Indonesia adalah insan yang layak diteladani dalam kehidupan bermasyarakat, berbangsa dan bernegara, khususnya oleh peserta didik, yang dalam melaksankan tugas berpegang teguh pada prinsip "ing ngarso sung tulodho, ing madya mangun karso, tut wuri handayani". Dalam usaha mewujudkan prinsip-prinsip tersebut guru Indonesia ketika menjalankan tugas-tugas profesionalnya dituntut memiliki kompetensi pedagogik, kompetensi kepribadian, kompetensi sosial, dan kompetensi profesional sesuai dengan perkembangan ilmu dan teknologi.

Guru Indonesia bertanggung jawab mengantarkan siswanya untuk mencapai kedewasaan sebagai calon pemimpin bangsa pada semua bidang kehidupan. Untuk itu, pihak-pihak yang berkepentingan selayaknya tidak mengabaikan peranan guru dan profesinya, agar bangsa dan negara dapat tumbuh sejajar dengan dengan bangsa lain di negara maju, baik pada masa sekarang maupun masa yang akan datang. Kondisi seperti itu bisa mengisyaratkan bahwa guru dan profesinya merupakan komponen kehidupan yang dibutuhkan oleh bangsa dan negara ini sepanjang zaman. Hanya dengan pelaksanaan tugas guru secara profesional hal itu dapat diwujudkan eksitensi bangsa dan negara yang bermakna, terhormat dan dihormati dalam pergaulan antar bangsa-bangsa di dunia ini.

\section{PERLINDUNGAN HUKUM PROFESI}

Dalam melaksanakan tugas profesinya guru Indonesia menyadari sepenuhnya bahwa diperlukannya Kode Etik Guru Indonesia sebagai pedoman bersikap dan berperilaku yang mengejewantah dalam bentuk nilai-nilai moral dan etika dalam jabatan guru sebagai pendidik putera-puteri bangsa.

Bagaimana mekanisme perlindungan profesi guru yang seharusnyya dilakukan dalah internal organisasi profesi. Secara umum dapat digambarkan dalam pedoman Kode Etik Guru sebagai berikut:

\section{Pasal 8}

\footnotetext{
1. Pelanggaran adalah perilaku menyimpang dan atau tidak melaksanakana Kode Etik Guru Indonesia dan ketentuan perundangan yang berlaku yang berkaitan dengan profesi guru.

2. Guru yang melanggar Kode Etik Guru Indonesia dikenai sanksi sesuai dengan ketentuan peraturan yang berlaku.

3. Jenis pelanggaran meliputi pelanggaran ringan, sedang, dan berat.
}

\section{Pasal 9}

1. Pemberian rekomendasi sanksi terhadap guru yang melakukan pelanggaran terhdap Kode Etik Guru Indonesia menjadi wewenang Dewan Kehormatan Guru Indonesia.

Pemberian sanksi oleh Dewan Kehormatan Guru Indonesia sebagaimana dimaksud pada ayat (1) harus

2. objektif, tidak diskriminatif, dan tidak bertentangan dengan anggaran dasar organisasi profesi serta peraturan perundang-undangan.

3. Rekomendasi Dewan Kehormatan Guru Indonesia sebagaimana dimaksud pada ayat (1) wajib dilaksanakan oleh organisasi profesi guru.

4. Sanksi sebagaimana dimaksud pada ayat (3) merupakan upaya pembinaan kepada guru yang melakukan pelanggaran dan untuk menjaga harkat dan martabat profesi guru. 

5. Siapapun yang mengetahui telah terjadi pelanggaran Kode Etik Guru Indonesia wajib melapor kepada Dewan Kehormatan Guru Indonesia, organisasi profesi guru, atau pejabat yang berwenang.
Setiap pelanggar dapat melakukan pembelaan diri dengan/atau tanpa bantuan organisasi profesi
6. guru dan/atau penasihat hukum sesuai dengan jenis pelanggaran yang dilakukan dihadapan Dewan Kehormatan Guru Indonesia.

Dugaan Pelanggaran Kode Etik Profesi $\rightarrow$ aturan hukum abstrak $\rightarrow$ organisasi profesi Dewan Kehormatan profesi $\rightarrow$ rekomendasi $\rightarrow$ Banding profesi $\rightarrow$ rekomendasi final

\section{BER ACARA DI DEWAN KEHORMATAN PROFESI}

\section{Pengaduan}

a. Para pihak yang menemukan terjadinya pelanggaran terhadap Kode Etik Guru Indonesia dapat mengajukan melalui surat pengaduan kepada DKGI Kab/Kota

b. Secara Tertulis, Dilengkapi Berbagai Identitas, Dan Bukti-Bukti Yang Memperkuat

\section{Dewan Kehormatan Guru kabupaten/kota/ Propinsi/ Pusat wajib:}

a. mempelajari identitas pengaduan yang diajukan;

b. mempelajari berkas-berkas sebagai bukti tertulis yang diajukan;

c. mengambil kesimpulan sementara absah dan tidaknya surat pengaduan tersebut;

d. Mempelajari masalah lebih dalam dengan:

1) mengundang pengadu

2) mengundang saksi

3) melakukan kunjungan ke tempat kejadian

4) mengundang pihak-pihak tertentu kalau perlu

5) sidang DKGI untuk bermusyawarah

\section{Pembuktian}

\section{Dapat Didampingi Kuasa Hukum /Bkbh Pgri/ Dari Luar Jika Perlu}

\section{Dkgi Dapat Menentukan Saksi Ahli/ Diutamakan Dari Pgri}

a. Tata Cara Persidangan Sebagaimana Ditentukan DKGI

b. Saksi Ahli ila perlu

c. Kesimpulan Dari Masing-Masing Fihak- DKGI PGRI

\section{Putusan}

a. Cara mengambil keputusan dalam sidang-sidang DKGI Provinsi dan atau Kabupaten/ Kota harus sesuai dengan yang ditentukan DKGI pusat

b. Keputusan yang diambil oleh DKGI dalam penanganan pelanggaran Kode Etik Guru Indonesia harus menyatakan dengan jelas bersalah atau tidak bersalah bagi teradu.

c. Keputusan harus dibedakan antara kesalahan ringan, sedang, dan berat

d. Penetapan kategori kesalahan didasarkan kepada kriteria:

1) akibat yang ditimbulkan terhadap kehormatan profesi;

2) keselamatan guru dan tenaga kependidikan lainnya;

3) itikad yang ditunjukan cukup, baik pihak teradu dalam membantu menyelesaikan persoalan dimaksud;

4) dorongan yang mendasari tumbuhnya kejadian yang bisa dipertimbangkan;

5) kondisi lingkungan yang dapat mempengaruhi tumbuhnya kejadian;

6) serta pendapat dan pandangan LKBH PGRI; 
e. Apabila kejadian yang dimaksud menyangkut pelanggaran hukum dan masalah tersebut sedang dalam proses hukum, maka hendaknya keputusan DKGI ditunda sampai dengan keputusan hukum tersebut.

f. DKGI harus mampu mencegah tumbuhnya proses hukum di pengadilan dengan upaya persidangan di DKGI tersebut.

\section{Rekomendasi Sanksidkgi}

a. Disampaikan pada Instansi pemeritah/penyelenggara yang terkait

b. Dalam hal sanksi yang langsung berhubungan dengan keanggotaan pada PGRI, maka PB PGRI dapat mencabut keanggotaan guru atau tenaga kependidikan tersebut bila DKGI memutuskan demikian

c. Sanksi yang diberikan akan tergantung kepada berat dan ringannya kesalahan yang dilakukan oleh pihak tertentu

d. Sanksi yang diberikan bisa berupa : (1) teguran; (2) peringatan tertulis; (3) penundaan pemberian hak; (4) penurunan pangkat; dan (5) pemberhentian dengan hormat; atau (6) pemberhentian tidak dengan hormat

e. Kalau keputusan oleh Instansi terkait berupa pemberhentian dengan hormat atau tidak hormat maksudnya adalah dalam waktu sementara melalui waktu yang telah ditentukan, dan pada masa ini diadakannya pembinaan dari pihak DKGI

f. Apabila selama waktu pemberhentain sementara, tidak terjadi perbaikan-perbaikan, maka akan ditetapkan pemecatan dan pemberhentian dari anggota/pengurus PGRI, yang diikuti dengan penyampaian rekomendasi kepada Instansi Departemen Pendidikan Nasional untuk diadakan tindakan seperlunya

g. Keputusan tentang pemecatan dan pemberhentian tetap dikirimkan kepada pengurus PGRI/DKGI PGRI Provinsi maupun PB PGRI

\section{Hak Banding}

a. Apabila kedua belah pihak antara pengadu dan teradu merasa tidak puas atas keputusan yang telah ditetapkan DKGI, maka keduanya bisa menyatakan untuk mengajukan naik banding

b. Naik banding sebagaimana ayat satu di atas merupakan tahap awal yang harus ditujukan kepada DKGI PGRI Provinsi, begitu pula selanjutnya bisa naik banding tahap yang kedua yang ditujukan ke tingkat DKGI Pusat

c. Tata cara pengakajian dan pengambilan keputusan pada pelaksanaan sidang-sidang pada dasarnya sama antara DKGI PGRI Provinsi dan atau Kabupaten/kota dengan di pusat

d. keputusan yang diambil DKGI Pusat pada dasarnya merupakan keputusan final dan mengikat yang tidak bisa diganggu gugat, kecuali datangnya keputusan lain melalui Kongres PGRI

\section{KESIMPULAN}

1. Terdapat alur logika normatif dari Pembukaan UUD NKRI 1945, Undang-Undang Nomor20 Tahun 2003, Undang-Undang Nomor 14 Tahun 2005, Keputusan Konggres ke XXI/ PGRI/ 2013 No.VI/Konggres/XXI/PGRI/ 2013 tentang Kode Etik Guru Indonesia Peraturan Dewan Kehormatan Dan Prosedur Operasional Kode Etik Guru Indonesia

2. Keberadaan PGRI sebagai organisasi profesi guru adalah melaksanakan amanah undangundang Guru

3. Pelanggaran Kode Etik Guru Indonesia sedapat mungkin diselesaikan berdasar mekanisme pada organisasi profesi. 
4. Putusan DKGI dapat dilakukan upaya banding ke DKGI diatasnya dan putusannnya bersifat final

5. Putusan DKGI adalah rekomendasi

6. Dalam hal sanksi yang langsung berhubungan dengan keanggotaan pada PGRI, maka PB PGRI dapat mencabut keanggotaan guru atau tenaga kependidikan tersebut bila DKGI memutuskan demikian

\section{DAFTAR PUSTAKA}

Undang-Undang Dasar Negara Republik Indonesia Tahun 1945

Undang-Undang Nomor 20 Tahun 2003 tentang Sistem Pendidikan Nasional

Undang-Undang Nomor 14 Tahun 2005 tentang Guru dan Dosen

Undang-Undang Nomor 30 Tahun 2003 tentang Pendidikan Nasional

Keputusan Konggres ke XXI/ PGRI/ 2013 No.VI/Konggres/XXI/PGRI/ 2013 tentang Kode Etik Guru Indonesia

Peraturan Dewan Kehormatan Dan Prosedur Operasional Kode Etik Guru Indonesia 